\title{
Final Flush of the Shielded Cells Melter
}

by

K. M. Marshall

Westinghouse Savannah River Company

Savannah River Site

Aiken, South Carolina 29808

T. L. Fellinger

J. R. Harbour

\section{MASTER}

\section{DOE Contract No. DE-AC09-96SR18500}

This paper was prepared in connection with work done under the above contract number with the U.S.

Department of Energy. By acceptance of this paper, the publisher and/or recipient acknowledges the U.S. Government's right to retain a nonexclusive, royalty-free license in and to any copyright covering this paper, along with the right to reproduce and to authorize others to reproduce all or part of the copyrighted paper. 


\section{DISCLAIMER}

This report was prepared as an account of work sponsored by an agency of the United States Government. Neither the United States Government nor any agency thereof, nor any of their employees, makes any warranty, express or implied, or assumes any legal liability or responsibility for the accuracy, completeness, or usefulness of any information, apparatus, product, or process disclosed, or represents that its use would not infringe privately owned rights. Reference herein to any specific commercial product, process, or service by trade name, trademark, manufacturer, or otherwise does not necessarily constitute or imply its endorsement, recommendation, or favoring by the United States Government or any agency thereof. The views and opinions of authors expressed herein do not necessarily state or reflect those of the United States Government or any agency thereof.

This report has been reproduced directly from the best available copy.

Available to DOE and DOE contractors from the Office of Scientific and Technical Information, P.O. Box 62, Oak Ridge, TN 37831; prices available from (615) 576-8401.

Available to the public from the National Technical Information Service, U.S. Department of Commerce; 5285 Port Royal Road, Springfield, VA 22161. 


\section{DISCLAIMER}

Portions of this document may be illegible electronic image products. Images are produced from the best available original document. 
September 29, 1997

\title{
FINAL FLUSH OF THE SHIELDED CELLS MELTER (U)
}

\author{
Kathryn M. Marshall, Terri L. Fellinger, John R. Harbour \\ Westinghouse Savannah River Company
}

\section{INTRODUCTION}

A flush of the Savannah River Technology Center (SRTC) Shielded Cells melter was performed after the completion of a campaign to vitrify loaded crystalline silicotitanate (CST) ion exchange medium. The purpose of the flush was to lower levels of radioisotopes accumulated during the campaign and to lower the level of titanium dioxide present in the glass. This in turn would ready the melter for future campaigns involving the Defense Waste Processing Facility (DWPF).

The CST campaign began in August and was completed in September of 1997. The material that was vitrified had been used to sorb cesium and strontium from the Melton Valley Storage Tanks at the Oak Ridge National Laboratory (ORNL). It was loaded primarily with Cesium-137, and with smaller amounts of strontium. ${ }^{1}$ At the beginning of the flush, the melter contained approximately ten kilograms of fifty-weight percent CSTloaded borosilicate glass. With this amount of glass, there was approximately 3.29 Curies in the melter ${ }^{2}$. In addition, the glass contained greater than one-weight percent titanium dioxide, a component of the CST. Constraints on the composition of DWPF glass limit titanium dioxide content to below one-weight percent. Approximately forty kilograms of the DWPF startup frit, black Frit 565, were used to flush this material out of the melter.

\section{NONRADIOACTIVE DWPF FEED}

Frit 565 is a borosilicate frit intended for startup activities in the DWPF. The frit formulation is shown in Table 1. The frit was first mixed with sea sand in the ratio of 9:1 and then fed to the melter in batches. Sea sand was added to the frit to increase the silica content, which served to decrease the liquidus temperature of the frit, and reduce crystal formation. Approximately forty kilograms of the frit and sand mixture were added to the melter for the flush. 
Table 1. Black Frit 565 Formulation ${ }^{3}$

\begin{tabular}{|c|c|}
\hline Componen & Weight \% \\
\hline $\mathrm{SiO}_{2}$ & 49 \\
\hline $\mathrm{B}^{2} \mathrm{O}_{3}$ & 8.8 \\
\hline $\mathrm{Li}_{2} \mathrm{O}$ & 3.5 \\
\hline $\mathrm{Na}_{2} \mathrm{O}$ & 11.5 \\
\hline $\mathrm{MgO}$ & 0.7 \\
\hline $\mathrm{CaO}$ & 1.2 \\
\hline $\mathrm{TiO}_{2}$ & 1 \\
\hline $\mathrm{Fe}_{2} \mathrm{O}_{3}$ & 13.5 \\
\hline $\mathrm{Al}_{2} \mathrm{O}_{3}$ & 4.7 \\
\hline $\mathrm{MnO}_{2}$ & 2.3 \\
\hline $\mathrm{NiO}$ & 1.1 \\
\hline $\mathrm{K}_{2} \mathrm{O}$ & 2.6 \\
\hline $\mathrm{Cr}_{2} \mathrm{O}_{3}$ & 0.1 \\
\hline
\end{tabular}

\section{MELTER FLUSH OPERATION}

At the end of the CST vitrification campaign, the SRTC Shielded Cells melter contained approximately ten kilograms of fifty-weight percent CST-loaded glass, at a level of approximately 3.29 Curies. $^{2}$ The glass also contained greater than the acceptable amount of titanium dioxide for DWPF composition control. In order to reduce the level of cesium and titanium, a flush was completed using DWPF black Frit 565.

The frit was added in batches via a funnel placed in the feed tube, located on top of the melter. Feedings took place in intervals of about twenty minutes. A feed batch was approximately 113 or $225 \mathrm{ml}$, depending on the rate the glass was pouring from the melter. During feeding, molten glass was poured into stainless steel beakers that each held approximately one kilogram of glass. By roughly matching the glass pour rate with the frit feed rate, the glass level in the melter remained essentially constant throughout flushing.

Total time of the feeding and pouring operation was approximately sixty-six hours. The total frit fed over the sixty-six hours was forty kilograms, and the total glass poured was thirty-nine kilograms. The glass was poured into thirty-six cans. See Attachment 1 for details of the flush. 


\section{RESULTS}

The Shielded Cells melter was flushed with DWPF black Frit 565 in order to reduce the levels of titanium and cesium in the vessel, as well as to prepare the melter for future campaigns. The thirty-nine kilograms of glass poured during the flush represent 3.9 turnovers of the melter volume. The concentration of cesium after 3.9 melter volumes is expected to be reduced to 0.0215 of its original concentration (See Attachment 2 for graphical analysis). With the initial loading of cesium contributing approximately 3.29 Curies $^{2}$ to the melter, the final concentration of cesium is expected to be reduced to 0.071 Curies. This corresponds to 0.0071 Curies per kilogram of glass in the melter. By the same calculation, the original concentration of titanium dioxide in the melter should be reduced to well below one-weight percent. ${ }^{2}$

\section{REFERENCES}

1. Joe Walker, LMER Pretreatment, OR1-6-WT-41, 1996.

2. M. K. Andrews, et al., "Vitrification of Cesium-Loaded Crystalline Silicotitanate in the Shielded Cells Melter", WSRC-TR-97-00314, September 1997.

3. C. M. Jantzen, "Glass Composition and Frit Formulations Developed for DWPF", DPST-88-952, November 1988. 


\begin{tabular}{|c|c|c|c|c|c|c|}
\hline Date & $\begin{array}{l}\text { Trme } \\
\text { Put In }\end{array}$ & Can & $\begin{array}{l}\text { Cumulative } \\
\text { Glass Poured (kg) }\end{array}$ & $\begin{array}{l}\text { Cumulative CST } \\
\text { Batch Fed (g) }\end{array}$ & $\begin{array}{l}\text { Cumulative } 565 \\
\text { Frit Fed (g) }\end{array}$ & NOTES \\
\hline & $15: 45$ & C31 & 1.1749 & & 2500.00 & \\
\hline & $16: 45$ & & & & & Toperation stopped; 1 bag frit fed \\
\hline \multirow[t]{3}{*}{ 9/4/97 } & $14: 00$ & & & & & Operation resumed \\
\hline & 16:20 & C32 & 2.1749 & & 346.55 & \\
\hline & 17:20 & C33 & 3.2174 & & 4116.38 & Operation stopped \\
\hline \multirow[t]{4}{*}{ 9/5/97 } & $9: 35$ & & & & & Operation resumed \\
\hline & $70: 35$ & C34 & 4.3764 & & 5086.21 & \\
\hline & 11:55 & $\mathrm{C35}$ & 5.5369 & & 6056.03 & \\
\hline & 12:45 & C36 & 6.6633 & & 7672.41 & Operation stopped; C36 empty \\
\hline \multirow[t]{8}{*}{ 9/8/97 } & $8: 40$ & & & & & Operation resumed \\
\hline & 10:00 & C37 & 7.7534 & & 8318.97 & \\
\hline & $11: 45$ & C38 & 8.7936 & & 9450.43 & \\
\hline & 13:50 & C39 & 9.8856 & & 10420.26 & \\
\hline & $15: 25$ & C40 & T0.9347 & & 71390.09 & \\
\hline & 17:10 & $\mathrm{C} 41$ & 11.6920 & & 12036.64 & \\
\hline & 18:00 & $\mathrm{C} 42$ & 12.7649 & & 13329.74 & \\
\hline & 18:40 & & & & & Operation stopped \\
\hline \multirow[t]{9}{*}{ 9/9/97 } & $6: 10$ & & & & & Operation resumed \\
\hline & $8: 00$ & C43 & 13.9399 & & 14461.21 & \\
\hline & $9: 45$ & C44 & 15.0929 & & 75592.67 & \\
\hline & $11: 20$ & $\mathrm{C45}$ & 16.0189 & & 16724.14 & \\
\hline & 13:05 & C46 & 37.0908 & & 17693.97 & \\
\hline & 14:40 & C47 & 18.1285 & & 18825.43 & \\
\hline & 16:40 & C48 & 19.2051 & & 19633.62 & \\
\hline & $18: 00$ & C49 & 20.2387 & & 21250.00 & \\
\hline & 38:40 & & & & & Operation stopped \\
\hline \multirow[t]{8}{*}{$9 / 10 / 97$} & $6: 10$ & & & & & Operation resumed \\
\hline & $8: 20$ & C50 & 21.2382 & & 22381.47 & \\
\hline & $10: 15$ & C51 & 22.2480 & & 23189.66 & \\
\hline & $11: 55$ & $\mathrm{C} 52$ & 23.4977 & & 24644.40 & \\
\hline & 13:50 & C53 & 24.5302 & & 25775.86 & \\
\hline & 15:30 & C54 & 25.6887 & & 26422.41 & \\
\hline & 16:35 & C55 & 26.6916 & & 27715.52 & \\
\hline & 77:50 & & & & & Operation stopped \\
\hline \multirow[t]{8}{*}{ 9/11/97 } & $6: 10$ & & & & & Operation resumed \\
\hline & $7: 35$ & C56 & 27.7374 & & 29008.62 & \\
\hline & $9: 35$ & C5T & 28.7880 & & 30140.09 & \\
\hline & 11:30 & C58 & 29.8434 & & 30786.64 & \\
\hline & T2:55 & C59 & 30.9015 & & 31756.47 & \\
\hline & 15:10 & 1060 & 31.9946 & & 32726.29 & \\
\hline & 77:10 & C61 & 33.1141 & & 34019.40 & \\
\hline & $18: 00$ & & & & & Operation stopped \\
\hline \multirow[t]{7}{*}{$9 / 15 / 97$} & $6: 05$ & & & & & Operation resumed \\
\hline & $8: 45$ & C62 & 34.1378 & & 35312.50 & \\
\hline & 10.55 & C63 & 35.3884 & & 36605.60 & \\
\hline & 12.55 & C64 & 36.4215 & & 38221.98 & \\
\hline & 15:00 & C65 & 37.6514 & & 39030.17 & \\
\hline & 16.50 & C66 & 38.7377 & & 40000.00 & \\
\hline & 18:10 & F30 & & & & Operation stopped; Can F30 in chamber \\
\hline
\end{tabular}


ATTACHMENT 2: Melter Turnover Graph

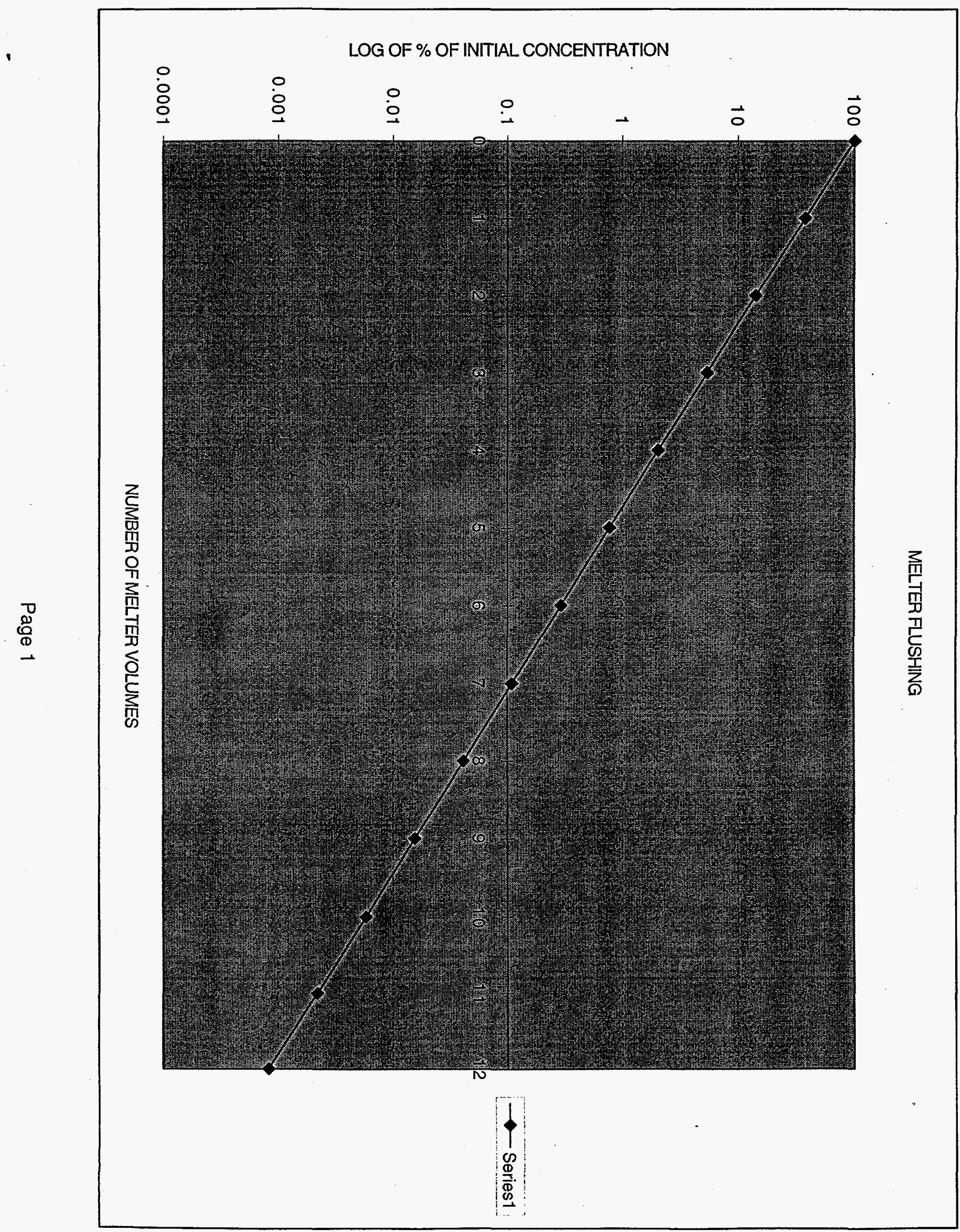

